\title{
Lycopene inhibits IL-6 expression in cerulein-stimulated pancreatic acinar cells
}

\author{
Miran Kang $\cdot$ Kyung Suk Park $\cdot$ Jeong Yeon Seo $•$ \\ Hyeyoung Kim
}

Received: 27 April 2010/Accepted: 20 November 2010/Published online: 5 December 2010

(C) Springer-Verlag 2010

\begin{abstract}
Reactive oxygen species (ROS) are known to be involved in the pathogenesis of acute and chronic pancreatitis. The cholecystokinin (CCK) analog cerulein causes pathophysiological, morphological, and biochemical events similar to those observed in human acute pancreatitis. The oxidant-sensitive transcription factor NF- $\kappa$ B plays a critical role in the development of cerulein pancreatitis by regulating the expression of pro-inflammatory cytokines in the pancreas. Lycopene has an anti-oxidant effect in various cells. In the present study, we investigated whether cerulein induces NF- $\kappa$ B activation and IL-6 expression in pancreatic acinar cells and whether lycopene inhibits these events. NF- $\kappa$ B-DNA-binding activity was determined by electrophoretic mobility shift assay, and mRNA expression was analyzed by reverse transcription-polymerase chain reaction (RT-PCR) and real-time RT-PCR analyses. The IL-6 concentration in the medium was determined by enzymelinked immunosorbent assay. Our results showed that cerulein induced IL-6 expression in a time-dependent manner. NF- $\kappa$ B-DNA-binding activity and intracellular levels of ROS in pancreatic acinar cells were increased by cerulein. Lycopene inhibited the cerulein-induced increase in intracellular ROS, NF- $\kappa$ B activation, and IL-6 expression in pancreatic acinar cells in a dose-dependent manner. In conclusion, lycopene may be beneficial in the prevention and/or treatment of acute pancreatitis by inhibiting the activation of NF- $\kappa \mathrm{B}$ and the expression of inflammatory cytokines through reduction in intracellular levels of ROS in pancreatic acinar cells.
\end{abstract}

M. Kang · K. S. Park · J. Y. Seo · H. Kim (凹) Department of Food and Nutrition, Brain Korea 21 Project, College of Human Ecology, Yonsei University,

Seoul 120-749, Korea

e-mail: kim626@yonsei.ac.kr
Keywords Lycopene $\cdot$ IL-6 - NF- $\kappa$ B $\cdot$ Cerulein $\cdot$ Pancreatic acinar cells

\section{Introduction}

Acute pancreatitis is an inflammatory disease associated with the activation and release of pancreatic enzymes in the interstitium, leading to autodigestion of the pancreas and multiple organ dysfunction after their release into the systemic circulation, and with increased production and release of cytokines, which can ultimately lead to deleterious local and systemic effects [1-3]. Similar symptoms are observed in experimental animal models treated with cerulein, a cholecystokinin (CCK) analog. Supramaximal doses of cerulein result in experimental pancreatitis, which is characterized by dysregulation of the production and secretion of digestive enzymes, in particular inhibition of pancreatic secretions, an elevation in serum enzyme levels, cytoplasmic vacuolization, death of acinar cells, edema formation, and infiltration of inflammatory cells into the pancreas $[4,5]$.

Oxidative stress is regarded a major pathogenic factor in acute pancreatitis [6]. In human acute pancreatitis, increased levels of lipid peroxide in the bile or pancreatic tissue and subnormal levels of antioxidant vitamins in the blood were reported [7-9]. Cerulein produces large amounts of reactive oxygen species (ROS), activates the oxidant-sensitive nuclear transcription factor NF- $\kappa \mathrm{B}$, and induces cytokine expression in vitro in freshly isolated pancreatic acinar cells in the absence of inflammatory cells [10].

Pancreatic inflammation is initiated by local production of mediators such as interleukin-1 $\beta$ (IL- $1 \beta$ ), interleukin-6 (IL-6), and interleukin-8 (IL-8) [11]. IL-6 is a pro-inflammatory cytokine that is produced by a wide range of cells including monocytes/macrophages, endothelial cells, 
fibroblasts, and smooth muscle cells in response to stimulation by endotoxin, IL- $1 \beta$, and TNF- $\alpha$ [12]. Elevated levels of IL- 6 have been described in a number of acute conditions such as burns, major surgery, and sepsis [13]. IL-6 levels are increased in patients with acute pancreatitis and correlate with disease severity [14].

Nuclear factor-B (NF- $\kappa \mathrm{B})$ is a pleiotropic transcription factor that regulates the activation of a wide variety of genes that respond to immune or inflammatory signals, including cytokine expression $[15,16]$. NF- $\kappa \mathrm{B}$ represents a family of proteins sharing the Rel homology domain, which bind to DNA as homodimers or heterodimers. $\mathrm{NF}-\kappa \mathrm{B}$ activates a multitude of cellular stress-related and inflammatory genes including IL-6. NF- $\kappa \mathrm{B}$ is kept silent in the cytoplasm via interaction with inhibitory proteins of the IB family and is activated by a variety of agents, including cytokines, mitogens, and ROS [17].

Lycopene, the most abundant carotenoid and responsible for the red color of tomatoes, is known to be an effective singlet oxygen quencher [18] and a potent antioxidant [19]. Epidemiological studies have indicated that elevated ingestion of tomatoes and tomato products containing lycopene is associated with a decreased risk of chronic diseases and cancers, especially pancreatic cancer [20, 21]. In addition, lycopene has anti-proliferation and pro-differentiation activities in various types of cancer cells including breast cancer, lung cancer, and endometrial cancer [22].

In the present study, we investigated whether the antioxidant lycopene inhibits NF- $\kappa \mathrm{B}$ activation and IL-6 expression in cerulein-stimulated pancreatic acinar cells.

\section{Materials and methods}

Isolation of pancreatic acinar cells

Pancreatic acinar cells were freshly isolated from Male Sprague-Dawley rats (200-220 g) by enzymatic digestion as previously described [10]. The acinar cells were cultured in Dulbecco's modified Eagle's medium (GIBCO, Grand Island, NY, USA) supplemented with $10 \%$ heat-inactivated fetal bovine serum (Lonza, Walkersvile, MD, USA), $0.1 \mathrm{mg} / \mathrm{ml}$ soybean trypsin inhibitor (Sigma Chemical Company, St. Louis, Missouri), and antibiotics (GIBCO). The cells were cultured at $37^{\circ} \mathrm{C}$ in a humidified atmosphere of $5 \% \mathrm{CO}_{2} / 95 \%$ air. The cell viability was determined by the trypan blue dye exclusion test; more than $95 \%$ of the cells survived after 24 -h culture.

\section{Experimental protocol}

The cells were stimulated with various concentrations of cerulein $\left(10^{-9}-10^{-7} \mathrm{M}\right)$ for $3 \mathrm{~h}$ (for mRNA expression,
Fig. 1a) or with $10^{-8} \mathrm{M}$ cerulein for the indicated time periods (for mRNA expression, Fig. 1b; IL-6 levels in the medium, Fig. 1c; and NF- $\kappa \mathrm{B}$ activation, Fig. 3a). Cells were treated with lycopene ( 2 or $5 \mu \mathrm{mol} / \mathrm{l}$ ) for $2 \mathrm{~h}$ prior to cerulein stimulation for $3 \mathrm{~h}$ (for mRNA expression, Fig. 2a), $6 \mathrm{~h}$ (for IL-6 levels in the medium, Fig. 2b), $30 \mathrm{~min}$ (for $\mathrm{NF}-\kappa \mathrm{B}$ activation, Fig. 3b), or $15 \mathrm{~min}$ (for ROS level, Fig. 3c). Lycopene (Sigma, St Louis, MO, USA) was dissolved in tetrahydrofuran (Sigma).

Reverse transcription-polymerase chain reaction (RT-PCR) and real-time RT-PCR analyses for IL-6 mRNA expression

Expression of IL-6 mRNA was assessed using RT-PCR analysis standardized by coamplification with the housekeeping gene GAPDH, which served as an internal control. Total RNA isolated from the cells was reverse transcribed into cDNA and used for PCR with primers specific for rat IL-6 and GAPDH. The IL-6 primer sequences were $5^{\prime}$-CT GGTCTTCTGGAGTTCCGTTTC-3' (forward primer) and $5^{\prime}$-CATAGCACACTAGGTTTGCCGAG-3' (reverse primer), giving a 302-bp PCR product. For GAPDH, the forward primer was $5^{\prime}$-ACCACAGTCCATGCCATCAC-3' and the reverse primer was 5'-TCCACCACCCTGTTG CTGTA-3', giving a 460-bp PCR product. After amplification for 28-30 cycles, the PCR products were separated on $1.5 \%$ agarose gel and visualized by UV transillumination.

IL-6 gene expression was quantified by real-time PCR using the Chromo4 detection system (MJ Research). cDNA was added to a SYBR Green Realtime PCR Master Mix(TOYOBO CO., Osaka, Japan) containing $30 \mathrm{pg} / \mathrm{ml}$ of IL-6 forward and reverse primers. The cDNA was amplified by 40 cycles of denaturation at $95^{\circ} \mathrm{C}$ for $15 \mathrm{~s}$, annealing at $60^{\circ} \mathrm{C}$ for $15 \mathrm{~s}$, and extension at $72^{\circ} \mathrm{C}$ for $45 \mathrm{~s}$. During the first cycle, the $95^{\circ} \mathrm{C}$ step was extended to $1 \mathrm{~min}$, and on the final cycle, the $65^{\circ} \mathrm{C}$ step was extended to $0.2 \mathrm{~s}$ to check the melting curve. The GAPDH gene was amplified in the same reaction to serve as the reference gene.

Electrophoretic mobility shift assay (EMSA)

for $\mathrm{NF}-\kappa \mathrm{B}$ activation

Cells were harvested, washed with PBS, and extracted with lysis buffer containing $10 \mathrm{mmol} / \mathrm{l}$ HEPES, $10 \mathrm{mmol} / \mathrm{L}$ $\mathrm{KCl}, \quad 0.1 \mathrm{mmol} / \mathrm{l}$ ethylene diamine tetra acetic acid (EDTA), $1.5 \mathrm{mmol} / \mathrm{l} \quad \mathrm{MgCl}_{2}, \quad 0.2 \% \quad \mathrm{NP}-40,1 \mathrm{mmol} / \mathrm{l}$ dithiothreitol (DTT), and $0.5 \mathrm{mmol} / \mathrm{l}$ phenylmethyl sulfonylfluoride (PMSF). The nuclear pellets were resuspended in nuclear extraction buffer containing $20 \mathrm{mmol} / \mathrm{l} \mathrm{HEPES}$, $420 \mathrm{mmol} / \mathrm{l} \mathrm{NaCl}, 0.1 \mathrm{mmol} / \mathrm{l}$ EDTA, $1.5 \mathrm{mmol} / \mathrm{l} \mathrm{MgCl}_{2}$, $25 \%$ glycerol, $1 \mathrm{mmol} / \mathrm{l} \mathrm{DTT}$, and $0.5 \mathrm{mmol} / 1 \mathrm{PMSF}$. The protein concentration of nuclear extract was determined by 

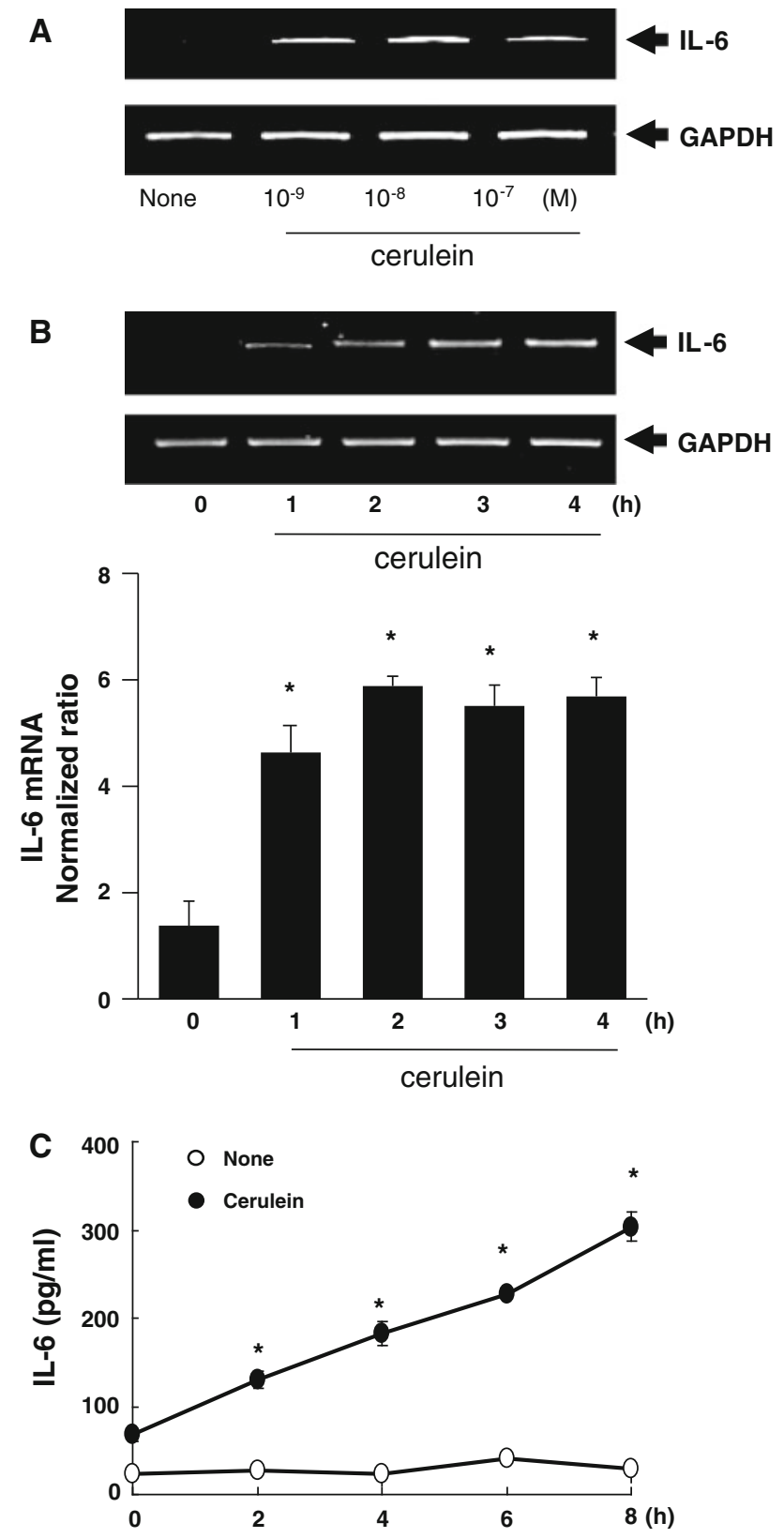

Fig. 1 Time-dependent expression of IL-6 in cerulein-stimulated pancreatic acinar cells. Acinar cells were treated with various concentrations of cerulein $\left(10^{-9}-10^{-7} \mathrm{M}\right)$ for $3 \mathrm{~h}$ (a, mRNA expression by RT-PCR analysis). The cells were then stimulated with cerulein $\left(10^{-8} \mathrm{M}\right)$ for the indicated time periods for mRNA expression analysis by RT-PCR (b, upper panel) and real-time RT-PCR analysis (b, lower panel). $* P<0.05$ versus $0 \mathrm{~h}$. $\mathbf{c}$ The amount of IL-6 released into the medium from cerulein-stimulated pancreatic acinar cells was determined by ELISA. The values are expressed as means \pm S.E. of four different experiments. $* P<0.05$ versus $0 \mathrm{~h}$

the Bradford assay using Bio-Rad protein assay solution (Bio-Rad Laboratories, Inc., Hercules, CA, USA). A NF- $\kappa$ B gel shift oligonucleotide (Promega Corp, Madison, WI, USA) was labeled with $\left[{ }^{32} \mathrm{P}\right]$ dATP using T4 polynucleotide kinase (GIBCO, Grand Island, NY, USA). The end-labeled
A
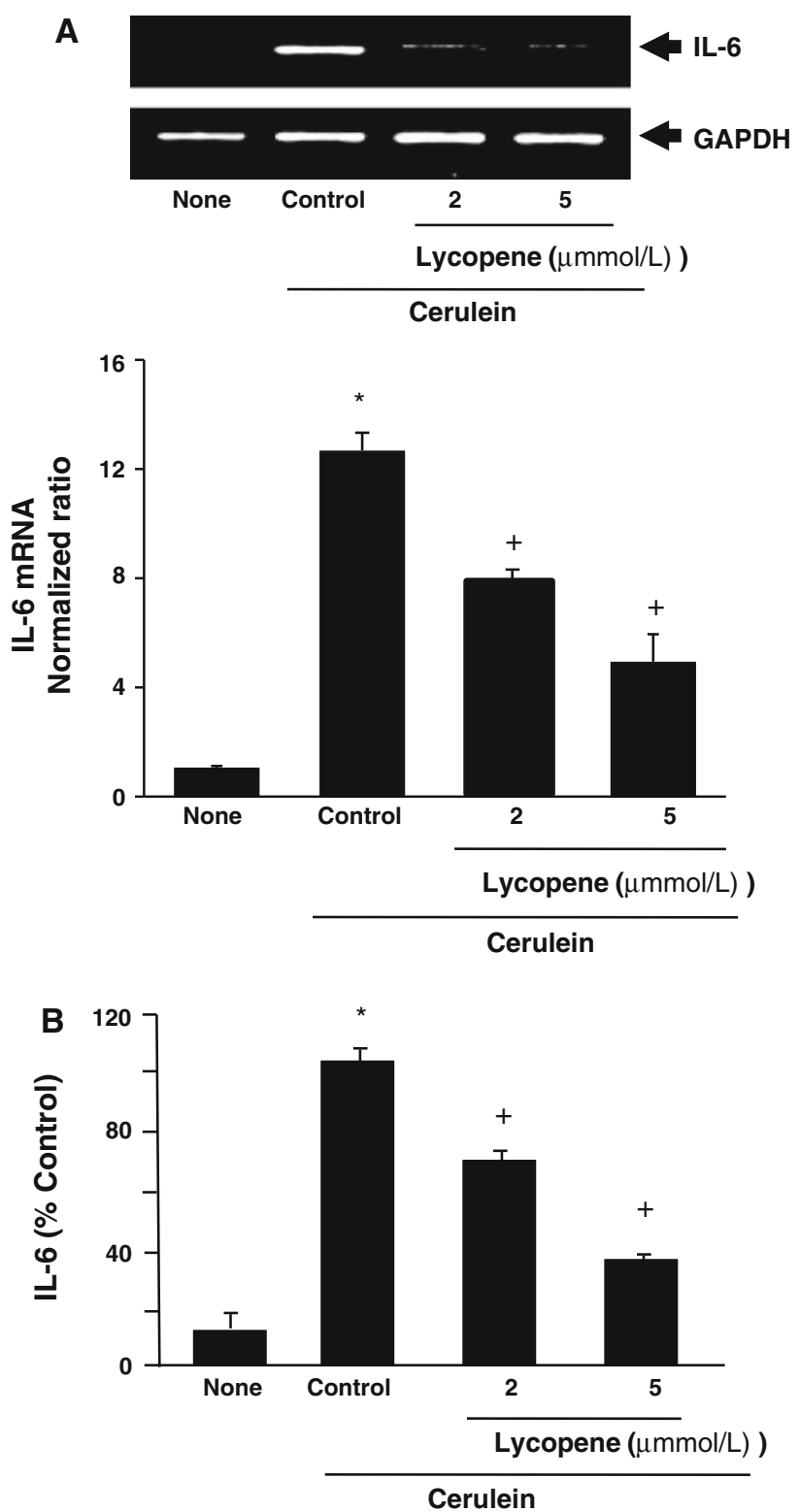

Fig. 2 Inhibitory effect of lycopene on IL-6 expression in ceruleinstimulated pancreatic acinar cells. Acinar cells were treated with lycopene $(2$ or $5 \mu \mathrm{mol} / \mathrm{l})$ for $2 \mathrm{~h}$ prior to stimulation with cerulein $\left(10^{-8} \mathrm{M}\right)$. The cells were stimulated with cerulein for $3 \mathrm{~h}$ (for mRNA expression, a) or $8 \mathrm{~h}$ (for IL-6 levels in the medium, b). mRNA expression of IL-6 was determined by RT-PCR analysis (a, upper panel) and by real-time RT-PCR analysis (a, lower panel). The IL-6 concentration in the medium was expressed as \% of control. None, without cerulein stimulation; Control, cells stimulated with cerulein. $* P<0.05$ versus none; ${ }^{+} P<0.05$ versus control

probe was purified from unincorporated $\left[{ }^{32} \mathrm{P}\right]$ dATP using a Bio-Rad purification column (Bio-Rad Laboratories) and recovered in Tris-EDTA buffer (TE). Nuclear extracts $(2 \mu \mathrm{g})$ were incubated with buffer containing ${ }^{32} \mathrm{P}$-labeled NF- $\kappa$ B consensus oligonucleotide for $30 \mathrm{~min}$ and subjected to electrophoretic separation on a nondenaturing acrylamide 
gel. The gels were dried at $80^{\circ} \mathrm{C}$ for $2 \mathrm{~h}$ and exposed to a radiography film at $-80^{\circ} \mathrm{C}$.

Enzyme-linked immunosorbent assay (ELISA) for IL-6

The concentration of IL-6 in the medium was determined using enzyme-linked immunosorbent assay kits (R\&D System, Minneapolis, MN, USA) according to the manufacturer's instructions.

Measurement of intracellular levels of ROS

Cells in a chamber slide (Nalge Nunc, Naperville, IL, USA) were pre-treated with lycopene for $2 \mathrm{~h}$ and stimulated with cerulein for $15 \mathrm{~min}$. The cells were washed with HBS and then loaded with $5 \mu \mathrm{g} / \mathrm{ml} 2^{\prime}, 7^{\prime}$-dichlorofluorescein diacetate (DCF; Molecular Probes, Eugene, OR, USA) for $5 \mathrm{~min}$. The fluorescent dichlorofluorescein was detected using a laser scanning confocal microscope (Leica TCSNT, Heidelberg, Germany) with excitation and emission wavelengths of 488 and $520 \mathrm{~nm}$, respectively [23]. The amount of ROS trapped in the cells was expressed relative to that of cells without cerulein stimulation, which was considered to be 1 .

\section{Statistical analysis}

Statistical differences were determined using one-way ANOVA and Newman Keul's test. All values were expressed as means \pm S.E. of four different experiments. A value of $P<0.05$ was considered statistically significant.

\section{Results}

Cerulein induced IL-6 expression in pancreatic acinar cells in a dose-dependent manner

mRNA expression of IL-6 in cerulein-treated pancreatic acinar cells was determined using RT-PCR and real-time RT-PCR analyses. The cells were stimulated with various concentrations of cerulein $\left(10^{-9}-10^{-7} \mathrm{M}\right)$ for $3 \mathrm{~h}$ (Fig. 1a). Cerulein induced expression of IL-6 mRNA at concentrations from $10^{-9}-10^{-7} \mathrm{M}$, and maximum stimulation of IL-6 mRNA expression was observed in the cells stimulated with $10^{-8} \mathrm{M}$ cerulein. When cells were treated with cerulein $\left(10^{-8} \mathrm{M}\right)$ for increasing time periods, IL-6 mRNA expression was evident from $1 \mathrm{~h}$ and increased up to $4 \mathrm{~h}$ by RT-PCR analysis (Fig. 1b, upper panel) and by real-time RT-PCR analysis (Fig. 1b, lower panel). GAPDH was constitutively expressed in pancreatic acinar cells and its expression was not changed by cerulein stimulation. As shown in Fig. 1c, the release of IL-6 into the medium by cerulein-stimulated pancreatic acinar cells increased with time up to $8 \mathrm{~h}$.

Lycopene inhibited IL-6 expression in ceruleinstimulated pancreatic acinar cells

Cells were treated with lycopene $(2$ or $5 \mu \mathrm{mol} / \mathrm{l})$ for $2 \mathrm{~h}$ prior to cerulein stimulation for $3 \mathrm{~h}$ (for mRNA expression, Fig. 2a) or 6 h (for IL-6 levels in the medium, Fig. 2b). Cerulein-induced mRNA expression of IL- 6 was inhibited by lycopene, as determined by RT-PCR analysis (Fig. 2a, upper panel) and by real-time RT-PCR analysis (Fig. 2a, lower panel). Lycopene also inhibited the cerulein-induced increase in IL-6 in the medium in a dose-dependent manner (Fig. 2b).

Cerulein-induced activation of NF- $\kappa \mathrm{B}$ and increased ROS levels in pancreatic acinar cells was inhibited by lycopene

To determine whether lycopene suppressed activation of the oxidant-sensitive transcription factor NF- $\kappa \mathrm{B}$, we measured NF- $\kappa$ B-DNA-binding activity in nuclear extracts of pancreatic acinar cells. A time course for activation of NF- $\kappa$ B showed that cerulein induced NF- $\kappa$ B activation from 30 to $120 \mathrm{~min}$ (Fig. 3a). Lycopene inhibited the cerulein-induced activation of NF- $\kappa \mathrm{B}$ at $30 \mathrm{~min}$ (Fig. 3b). Cerulein also induced an increase in intracellular levels of ROS (Fig. 3c), which was suppressed by treatment with lycopene in a dose-dependent manner.

\section{Discussion}

In the present study, we showed that lycopene has an inhibitory effect on NF- $\kappa$ B activation and IL- 6 expression in pancreatic acinar cells, which is associated with inhibition of the increase in ROS levels in cells stimulated with cerulein. In previous studies on the antioxidant effect of lycopene, lycopene inhibited nitration of proteins and DNA strand breakage caused by peroxynitrite treatment [24] and decreased the oxidative DNA damage caused by the redoxcycling of catechol-estrogens [25] in Chinese hamster lung fibroblasts. In Hep3B cells treated with $\mathrm{H}_{2} \mathrm{O}_{2}$, lycopene suppressed DNA damage in a dose-dependent manner [26]. Liu et al. [27] determined the subcellular localization of lycopene in prostate cancer cells and found that $81 \%$ of the lycopene was localized to the nucleus. These results support an antioxidant effect of lycopene in various cells. The present study indicates that the inhibitory effect of lycopene on cerulein-induced activation of NF- $\kappa \mathrm{B}$ may be caused by the ROS scavenging activity of lycopene in the cells. 
Fig. 3 Inhibitory effect of lycopene on NF- $\kappa \mathrm{B}$ activation and ROS production in ceruleinstimulated pancreatic acinar cells. Acinar cells were stimulated with cerulein $\left(10^{-8} \mathrm{M}\right)$ for the indicated time periods (a). The cells were treated with lycopene ( 2 or $5 \mu \mathrm{mol} / \mathrm{l})$ for $2 \mathrm{~h}$ prior to stimulation with cerulein $\left(10^{-8} \mathrm{M}\right)$ for $30 \mathrm{~min}$ for determination of NF- $\kappa \mathrm{B}$ activation by EMSA (b) or 15 min for measurement of intracellular levels of ROS (c). DCF fluorescence for ROS was detected on a laser scanning confocal microscope. The amount of ROS trapped in the cells was expressed as the increase relative to that of cells without cerulein stimulation, which was considered to be 1 (None). The values are expressed as means \pm S.E. of four different experiments. $* P<0.05$ versus none control (without lycopene and without cerulein stimulation).

$+P<0.05$ versus cerulein control (without lycopene and with cerulein stimulation)
A

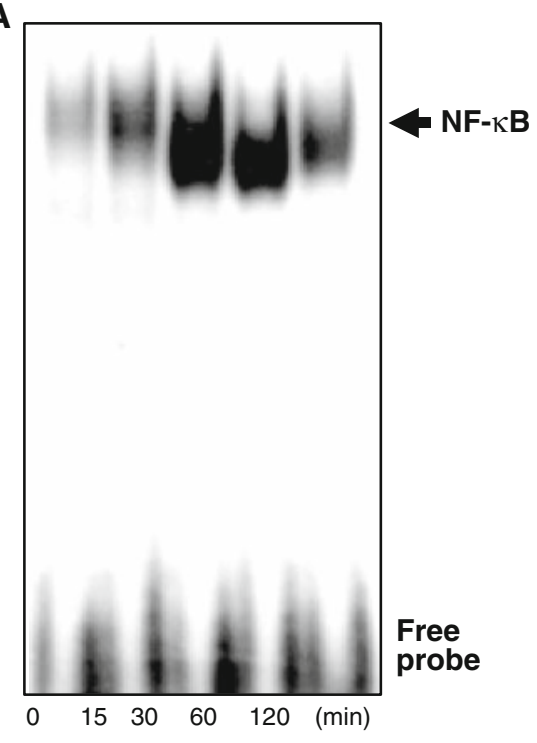

$\begin{array}{lllll}15 & 30 & 60 & 120 & (\min )\end{array}$

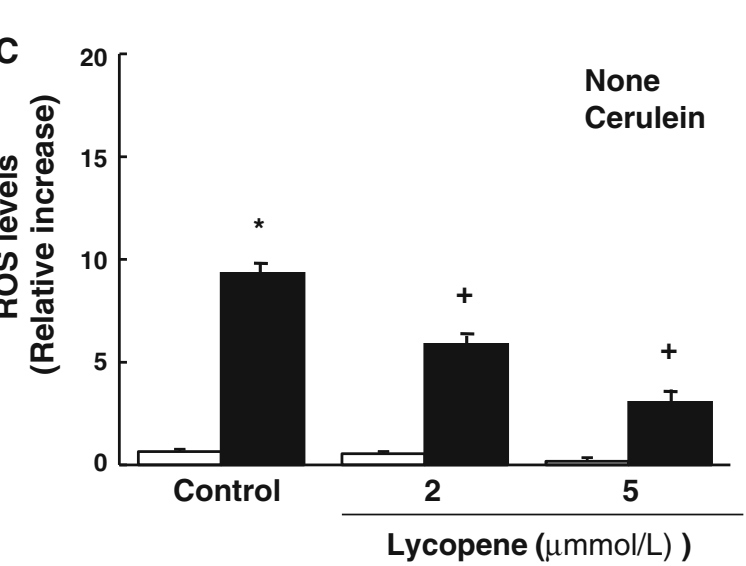

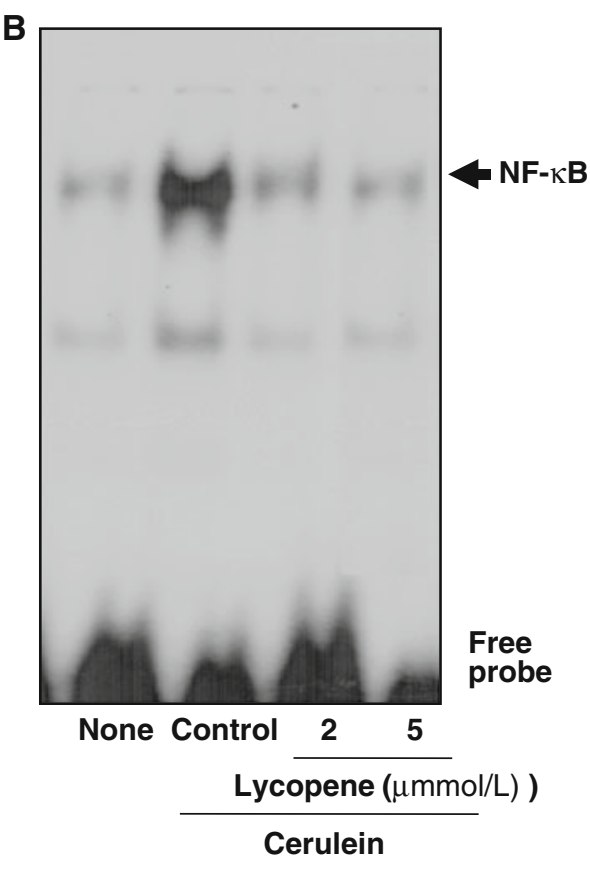

Cerulein
The first reported in vivo biological activities of lycopene were protection of mice against bacterial infection [28] and protection against radiation and development of specific types of ascites tumors [29]. Recent studies have focused more on the beneficial effect of lycopene in prostate cancer chemoprevention [30]. Lycopene supplementation has been shown to reduce IL-6 levels in disabled older women [31]. In addition, lycopene interferes with autocrine/paracrine loops in the Dunning prostate cancer model [32] and inhibits the expression of IL-6 in prostate cancer $[32,33]$.

Lycopene inhibits lipopolysaccharide-induced activation of NF- $\kappa$ B by suppressing the phosphorylation of I- $\kappa$ B and thus protecting it from degradation. The inhibitory effect of lycopene on NF- $\kappa$ B activation results in inhibition of IL-6 expression in prostate cancer [34]. Lycopene shows inhibitory effects on TNF- $\alpha$-induced activation of NF- $\kappa \mathrm{B}$ and ICAM-1 expression in human umbilical endothelial cells
[35]. Moreover, lycopene inhibits the lipopolysaccharideinduced phenotypic and functional maturation of murine dendritic cells by suppressing the activation of NF- $\kappa \mathrm{B}$ and mitogen-activated protein kinases [36]. These studies demonstrate a possible relationship between NF- $\kappa$ B activation and IL- 6 expression, indicating that inhibition of NF- $\kappa$ B activation may result in inhibition of IL-6 expression.

Regarding the anti-inflammatory mechanisms of lycopene, Palozza et al. have recently shown that lycopene increases levels of peroxisome proliferator-activated receptor $\gamma(\operatorname{PPAR} \gamma)$ concomitant with inhibition of ROS production and NF- $\kappa \mathrm{B}$ activation in a model of atherosclerosis [37]. The PPAR $\gamma$ receptor agonist rosiglitazone has been found to alleviate the inflammatory response in experimental-induced pancreatitis [38]. Moreover, in a cerulein-treated pancreatic acinar cell model, the PPAR $\gamma$ receptor agonist pioglitazone attenuates NF- $\kappa \mathrm{B}$ activity [39]. 
Since NF- $\kappa$ B activation is induced by oxidants, the antioxidant effect of lycopene may contribute to inhibition of NF- $\kappa \mathrm{B}$ activation and IL-6 expression in pancreatic acinar cells. Lycopene may be beneficial in the prevention and/or treatment of acute pancreatitis by inhibiting activation of NF- $\kappa \mathrm{B}$ and the expression of inflammatory cytokines in pancreatic acinar cells. Further studies should be performed to investigate the precise mechanism by which the potent antioxidant lycopene exerts anti-inflammatory effects in pancreatic acinar cells by determining the oxidant-mediated inflammatory signaling pathways involved.

Acknowledgments This study was supported by the Basic Science Research Program through the National Research Foundation of Korea (NRF) funded by the Ministry of Education, Science and Technology (2010-0001669) and a grant (Joint Research Project under the Korea-Japan Basic Scientific Cooperation Program) from NRF (F01-2009-000-10101-0). H. Kim is grateful to the Brain Korea 21 Project, college of Human Ecology, Yonsei University.

\section{References}

1. Bhatia M, Wong FL, Cao Y, Lau HY, Huang J, Puneet P, Chevali L (2005) Pathophysiology of acute pancreatitis. Pancreatology 5:132-144

2. Saluja AK, Steer ML (1999) Pathophysiology of pancreatitis: role of cytokines and other mediators of inflammation. Digestion 60:27-33

3. Frossard JL, Hadengue A, Pastor CM (2001) New serum markers for the detection of severe acute pancreatitis in humans. Am J Respir Crit Care Med 164:162-170

4. Hofbauer B, Saluja AK, Lerch MM, Bhagat L, Bhatia M, Lee HS, Frossard JL, Adler G, Steer ML (1998) Intra-acinar cell activation of trypsinogen during caerulein-induced pancreatitis in rats. Am J Physiol 275:G352-G362

5. Lerch MM, Adler G (1994) Experimental animal models of acute pancreatitis. Int J Pancreatol 15:159-170

6. Schoenberg MH, Büchler M, Gaspar M, Stinner A, Younes M, Melzner I, Bültmann B, Beger HG (1990) Oxygen free radicals in acute pancreatitis of the rat. Gut 10:1138-1143

7. Park BK, Chung JB, Lee JH, Suh JH, Park SW, Song SY, Kim H, Kim KH, Kang JK (2003) Role of oxygen free radicals in patients with acute pancreatitis. World J Gastroenterol 10:2266-2269

8. Scott P, Bruce C, Schofield D, Shiel N, Braganza JM, McCloy RF (1993) Vitamin C status in patients with acute pancreatitis. Br J Surg 80(6):750-754

9. Schoenberg MH, Birk D, Beger HG (1995) Oxidative stress in acute and chronic pancreatitis. Am J Clin Nutri 62(6):1306S$1314 \mathrm{~S}$

10. Yu JH, Lim JW, Namkung W, Kim H, Kim KH (2002) Suppression of cerulein-induced cytokine expression by antioxidants in pancreatic acinar cells. Lab Invest 82(10):1359-1368

11. Bhatia M, Brady M, Shokuhi S, Christmas S, Neoptolemos JP, Slavin J (2000) Inflammatory mediators in acute pancreatitis. J Pathol 190:117-125

12. Scholmerich J (1996) Interleukins in acute pancreatitis. Scand J Gastroenterol Suppl 219:37-42

13. Nijsten MW, Hack CE, Helle M, Duis HJ, Klasen HJ, Aarden LA (1991) Interleukin-6 and its relation to the humoral immune response and clinical parameters in burned patients. Surgery 109(6):761-767
14. Leser HG, Gross V, Scheibenbogen C, Heinisch A, Salm R, Lausen M, Ruckauer K, Andreesen R, Farthmann EH, Scholmerich J (1991) Elevation of serum interleukin-6 concentration precedes acute-phase response and reflects severity in acute pancreatitis. Gastroenterology 101(3):782-785

15. Barnes PJ, Karin M (1997) Nuclear factor- $\kappa$ B: a pivotal transcription factor in chronic inflammatory diseases. N Engl J Med 336:1066-1071

16. Wulczyn FG, Krappmann D, Scheidereit C (1996) The NF- $\kappa \mathrm{B} /$ Rel and $\mathrm{I} \kappa \mathrm{B}$ gene families: mediators of immune response and inflammation. J Mol Med 74:749-769

17. Meyer M, Schreck R, Baeuerle PA (1993) Hydrogen peroxide and antioxidants have opposite effects on activa-tion of NF- $\kappa \mathrm{B}$ and AP-1 in intact cells: AP-1 as secondary antioxidant-responsive factor. EMBO J 12:2005-2015

18. Di Mascio P, Kaiser S, Sies H (1989) Lycopene as themost efficient biological carotenoid singlet oxygen quencher. Arch Biochem Biophys 274:532-538

19. Stahl W, Junghans A, de Boer B et al (1998) Carotenoid mixtures protectmultilamellar liposomes against oxidative damage: synergistic effects of lycopene and lutein. FEBS Lett 427:305-308

20. Abiaka CD, Al-Awadi FM, Al-Sayer H et al (2001) Plasma micronutrient antioxidant in cancer patients. Cancer Detect Prev $25: 245-253$

21. Nkondjock A, Ghadirian P, Johnson KC et al (2005) Dietary intake of lycopene is associated with reduced pancreatic cancer risk. J Nutr 135:592-597

22. Levy J, Bosin E, Feldman B et al (1995) Lycopene is amore potent inhibitor of human cancer cell proliferation than either alpha-carotene or beta-carotene. Nutr Cancer 24:257-266

23. Yu JH, Kim KH, Kim DG, Kim H (2007) Diphenyleneiodonium suppresses apoptosis in cerulein-stimulated pancreatic acinar cells. Int J Biochem Cell Biol 39:2063-2075

24. Muzandu K, Ishizuka M, Sakamoto KQ, Shaban Z, El Bohi K, Kazusaka A, Fujita S (2006) Effect of lycopene and betacarotene on peroxynitrite-mediated cellular modifications. Toxicol Appl Pharmacol 215:330-340

25. Muzandu K, El Bohi K, Shaban Z, Ishizuka M, Kazusaka A, Fujika S (2005) Lycopene and beta-carotene ameliorate catechol estrogen-mediated DNA damage. Jpn J Vet Res 52:173-184

26. Park YO, Hwang ES, Moon TW (2005) The effect of lycopene on cell growth and oxidative DNA damage of Hep3B human hepatoma cells. Biofactors 23:129-139

27. Liu A, Pajkovic N, Pang Y, Zhu D, Calamini B, Mesecar Al, van Breemen RB (2006) Absorption and subcellular localization of lycopene in human prostate cancer cells. Mol Cancer Ther 5:2879-2885

28. Lingen C, Ernster L, Lindberg O (1959) The promoting effect of lycopene on the non-specific resistance of animals. Exp Cell Res $16: 384-393$

29. Forssberg A, Lingen C, Ernster L, Lindberg O (1959) Modification of the $\mathrm{x}$-irradiation syndrome by lycopene. Exp Cell Res 16:7-14

30. Tang L, Jin T, Zeng X, Wang JS (2005) Lycopene inhibits the growth of human androgen-independent prostate cancer cells in vitro and in BALB/c nude mice. J Nutr 135:287-290

31. Walston J, Xue Q, Semba RD, Ferrucci L, Cappola AR, Ricks M, Guralnik J, Fried LP (2006) Serum antioxidants, inflammation, and total mortality in older women. Am J Epidemiol 163(1):18-26

32. Siler U, Barella L, Spitzer V, Schnorr J, Lein M, Goralczyk R, Wertz K (2004) Lycopene and vitamin E interfere with autocrine/ paracrine loops in the Dunning prostate cancer model. FASEB J 18(9):1019-1021

33. Giri D, Ozen M, Ittmann M (2001) Interleukin-6 is an autocrine growth factor in human prostate cancer. Am J Pathol 159:2159-2165 
34. Feng D, Ling WH, Duan RD (2010) Lycopene suppresses LPSinduced NO and IL-6 production by inhibiting the activation of ERK, p38MAPK, and NF-kappaB in macrophages. Inflamm Res 59(2):115-121

35. Hung CF, Huang TF, Chen BH, Shieh JM, Wu PH, Wu WB (2008) Lycopene inhibits TNF-alpha-induced endothelial ICAM1 expression and monocyte-endothelial adhesion. Eur J Pharmacol 586:275-282

36. Kim GY, Kim JH, Ahn SC, Lee HJ, Moon DO, Lee CM, Park YM (2004) Lycopene suppresses the lipopolysaccharide-induced phenotypic and functional maturation of murine dendritic cells through inhibition of mitogen-activated protein kinases and nuclear factor-kappaB. Immunology 113(2):203-211

37. Palozza P, Simone R, Catalano A, Monego G, Barini A, Mele MC, Parrone N, Trombino S, Picci N, Ranelletti FO (2010) Lycopene prevention of oxysterol-induced proinflammatory cytokine cascade in human macrophages: inhibition of NF-kappaB nuclear binding and increase in PPARgamma expression. Nutr Biochem, Epub ahead of print

38. Celiński K, Madro A, Prozorow-Król B, Korolczuk A, Cichoz-Lach H, Słomka M, Korobowicz E (2009) Rosiglitazone, a peroxisome proliferator-activated receptor gamma (PPARgamma)-specific agonist, as a modulator in experimental acute pancreatitis. Med Sci Monit 15(1):BR21-BR29

39. Wan H, Yuan Y, Qian A, Sun Y, Qiao M (2008) Pioglitazone, a PPARgamma ligand, suppresses NFkappaB activation through inhibition of IkappaB kinase activation in cerulein-treated AR42J cells. Biomed Pharmacother 62(7):466-472 